S. KALIDINDI, A. S. GANGU, S. KUPPUSAMY, S. SATHASIVAM, V. SHEKARAPPA,

S. MURUGAN, S. BONDIGELA, M. KANDASAMY, K. GHANTA, A. VINODINI, A. SHRIKANT, R. RAMACHANDRAN, W. P. GALLAGHER, N. KOPP, F. GONZÁLEZ-BOBES*,

M. D. EASTGATE, R. VAIDYANATHAN* (BRISTOL-MYERS SQUIBB, NEW BRUNSWICK, USA AND BRISTOL-MYERS SQUIBB RESEARCH AND DEVELOPMENT CENTER, BANGALORE, INDIA)

Development of a Scalable Synthetic Route to BMS-986251, Part 2: Synthesis of the Tricyclic Core and the API Org. Process Res. Dev. 2021, 25, 1556-1572, DOI: 10.1021/acs.oprd.1c00125.

\section{Synthesis of the Tricyclic Core of BMS-986251}

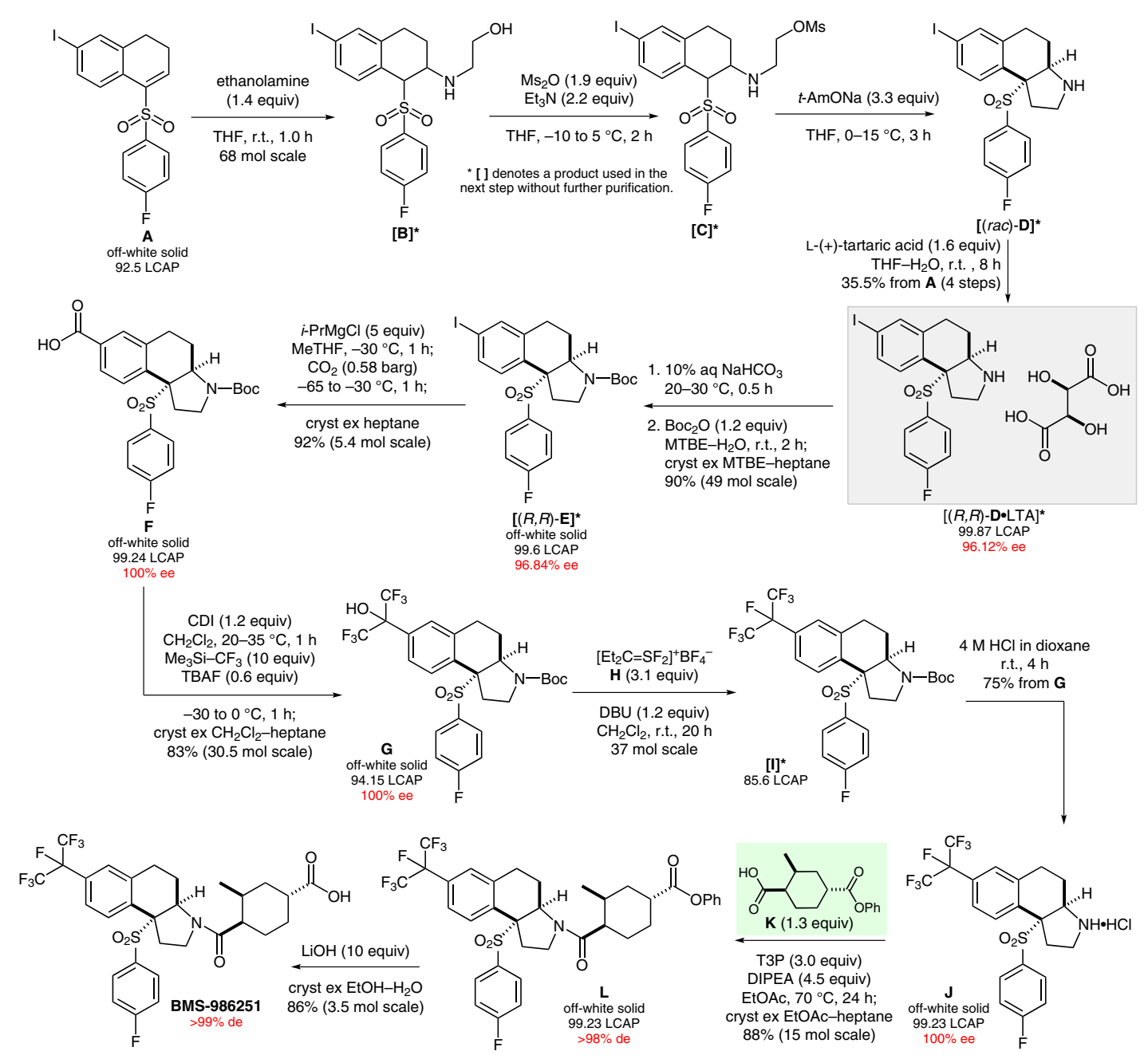

\section{Category}

Synthesis of Natural

Products and

Potential Drugs

\section{Key words}

BMS-986251

halogen-metal exchange

deoxyfluorination

annulation
Significance: ROR $\gamma \mathrm{t}$ is a nuclear receptor that regulates the production of proinflammatory cytokines, such as IL-17 and IL-22. BMS-986251 is a ROR $y$ inverse agonist that is of interest for the treatment of immunological disorders. For syntheses of related analogues, see: D. Marcoux et al. J. Med. Chem. 2019, 62, 9931; A. Karmakar et al. Org. Process Res. Dev. 2021, 25, 1001.
Comment: Highlights of the synthesis of BMS986251 depicted are (1) a high-yielding four-step aza-Michael addition/mesylation/annulation sequence to form the tricyclic core, and (2) installation of the heptafluoroisopropyl moiety through a three-step carboxylation-bistrifluoromethylationdeoxyfluorination sequence. 